\title{
ANALISIS MAKNA TATO SEBAGAI MEDIA EKSPRESI DIRI
}

\author{
Oleh: \\ RESTY AMANDA, SRI NARTI, BAYU RISDIYANTO \\ Program Studi Ilmu Komunikasi Fakultas Ilmu-Ilmu Sosial \\ Universitas Dehasen Bengkulu
}

\begin{abstract}
The rise of the use of tattoos at this time is proof that the elements of cultural order and people'spattern of thought have changed especially in Bengkulu city. Tattoos ware once a sign of crime, but nows tattoos have become commonplace and even today tattoos have become a medium of art of self-expression that carries meanings of one's life journey. This study aims to determine self-expression and the meaning of tattoos as a medium of selfexpression in the tattoo userscommunity users in Bengkulu city. This research uses Charles Sanders Peirce theory and method of data analysis techniques (triangel meaning) which consists of signs, object (object), interpreters (interpretant). To convince the results of the analysis in this study, the authors chose several informants consisting of 5 informan namely 3 men and 2 women with different forms of tattoos. The results of this study prove that tattoos are symbolic art that can be a medium for someone to express themselves disappointed selfexpression, love, self-identity and others. Referring to the sign consists of qualisign that we can see in the tattoo of a rose-headed skull, the sinsignnamely tattoo scissors and a sewing machine and legisianis skull-headed pineapple tattoo. The second is an object consists of an icon that is the faces tattoo of the queens such as Queen DwiSiren, Queen Isabella I, then index the arrow tattoos and the tattoos of the faces of the two boys. Symbol is the queen's face figure tattoo and Doraemon and Tinkerbell cartoon characters. The third interpretant consists of rhemes, namely rose tattoos and then signedare tattoo scissors and sewing machines and the last argument is all the reasons why the informant made the tattoo. Tattoos on a person's body have meanings such as meaning of the expressions of love for two boys, a birthday presents for the wife, a form of affection for the mother, disappointed the be born in the midst of a broken home family, hope of having a life like a queen and others.
\end{abstract}

Keywords: tattoos, self-expression media, semiotic

\section{PENDAHULUAN}

Tato merupakan suatu wahana identitas yang menyebar tidak hanya di belahan dunia barat, tetapi juga mulai mewabah di Indonesia. Pada saat ini tato mempunyai peran yang lebih melebar melebihi perannya pada masa lalu. Seiring berjalanya waktu dan berkembangnya zaman banyak masyarakat yang dapat menerima bahwa tato tidak terkait dengan unsure budaya saja.
Tato adalah salah satu kegiatan seni menggambar pada kulit tubuh menggunakan alat sejenis jarum dan ditunjang oleh alat-alat canggih lainnya, dan yang terpenting proses penatoan pada zaman sekarang tidaklah menakutkan dan menyakitkan seperti pada zaman dahulu, yang mana sekarang ini proses tato tidak lagi merasakan sakit karena adanya bius dan krimanastesi yang telah banyak beredar di pasaran. 
Menurut Olong (2006:16) dalam perkembangannya tato mengalami proses adaptasi, menyesuaikan dengan paradigma yang berkembang pada masyarakat modern, tidak lagi bersifat tradisional yang identik dengan tradisi ritual dan identitas kedaerahan, tetapi berfungsi sebagai media ekspresi diri yang membawa nilai-nilai identitas perlawanan, pencarian identitas, luapan cinta, untuk kesenangan atau kenyamanan bagi penggunanya.

Hal ini senada dengan hasil penelitian Adi Saputera (2014) tentang Makna Tato Dalam Konteks Citra Diri Di Kalangan Remaja dengan pendapat sebagai berikut, bahwasanya tato yang ada pada tubuh informan sebagai fashion dan ingin menunjukan pada orang lain bahwa tato itu adalah seni dimana mereka merasa puas dan bisa mengeskpresikan dirinya melalui tato. Mereka merasa senang dan bangga mencintai tato, tat $\mathrm{o}$ adalah pelajaran terbaik untuk belajar memahami, dan mengenal indahnya seni kehidupan.

Keberadaan tato pada masyarakat modern perkotaan kini telah mengalami perubahan makna. Apabila dulu budaya tato hanya menjadi symbol bagi kalangan tertentu, maka kini tato menjadi konsumsi bagi banyak kalangan tanpa melihat dan merasa bahwa individu tersebut sedang memasuki suatu keadaan tertentu dengan tato sebagai simbolnya. Hal tersebut juga merupakan bukti penguat bahwa tato menjelma dari tradisi dengan budaya tinggi (high culture) menjadi budaya pop (pop culture), dimana dari kalangan artis hingga preman merasa nyaman menggunakannya. Olong (2006:12).

Fenomena orang menggunakan tato semakin hari semakin bertambah hal tersebut dibuktikan pada semakin bertambahnya studio pembuatan tato yang ada. Pada awalnya untuk dikota Bengkulu sendiri tato masih di buat dengan hanya bermodalkan jarum yang dipanaskan sehingga gambar yang dihasilakan hanya berwarna hijau saja, di sisi lain jika ada masyarakat kota Bengkulu yang ingin menggunakan tato dengan alat yang berkelas dan hasil yang memuaskan maka mereka harus ke kota-kota besar seperti Jakarta dan Bandung, menurut observasi awal yang dilakukan oleh peneliti, sekarang ini di kota Bengkulu sudah ada 5 studio tato yang telah memiliki alat penunjang pembuatan tato canggih di sisi lain para pengguna tato yang ada di kota Bengkulu ini tidak lagi takut untuk memperlihatkan tato yang ada di badan mereka, alat pembuatan tato seperti mesin tato, jarum, green soap, petroleum atau vaseline, ink cup, tinta pigmen, sarung tangan dll. Secaratidaklangsunghaltersebut juga menambah angka pengguna tato sendiri. Pengguna tato sekarang ini berasal dari semua kalangan mulai dari kalangan bawah, menengah dan kalangan atas. Hal ini menjadi penting mengigat dulu tato banyak digunakan oleh kalangan bawah seperti preman dan orang yang pendidikannya rendah. Pengguna tato sering menerima pandangan negatif dari masyarakat umum terkhususnya masyarakat di Kota Bengkulu, pandangan negative tersebut menggambarkan bahwa pengguna tato merupakan pelaku kriminal dan harus dihindari.

Pandangan tersebut sejatinya bukan tanpa alas an bahwasanya pelaku criminal atau orang-orang pelanggar hokum memang kebanyakan memakai tato, hal tersebut dapat kita lihat di dalam penjara. Pada dasarnya pandangan yang demikian bisa kita katakana terlalu subjektif dalam menilai sesuatu individu. Tidak semua individu yang bertato itu pelaku criminal ataupun orang yang harus di hindari, karena tidak sedikit orang yang melakukan tindakan kriminal malah tidak memiliki tato sama sekali.

Namun sekarang, justru masyarakat dari kalangan atas yang lebih banyak menggunakan tato. Posisi tato secara tidak langsung dapat dilihat pada posisi lengan, leher, dan bagian terbuka lainnya. Penggunaan gambar tato sangat beragam tergantung keinginan para pengguna tato, sehingga banyak variasi motif tato. Setiap individu mempunyai pemahaman 
tersendiri mengenai letak dan gambar yang digunakannya, bahkan gambar abstrak yang cenderung hanya pemilik yang mengerti maknanya. Sekarang ini tato tidak lagi hanya didominasi oleh kaum pria saja, namun termasuk wanita. Sebagian dari mereka bahkan menggunakan pakaian yang cenderung memperlihatkan tato mereka. Menurut Kassandra (Aldy, 2007), wanita bertato cenderung mengarah tipikal wanita yang eksibisionis. Kebanggaan dan keinginan menampilkan tato yang ada di bagian tertentu tubuhnya, termasuk kategori eksibisionis. Seolah wanita bertato ingin memperlihatkan sisi kelembutannya dengan mewujudkan sebuah tato yang indah.

Hal tersebut di tunjang oleh hasil penelitian Wanda Amalia Santoso (2017) tentang Memahami Power Dan Komunikasi Identitas Diri Perempuan Melalui Tato, bahwasanya tato dapat menjadi komunikasi non verbal yang dapat digunakan oleh perempuan, komunikasi keluarga yang kurang baik membuat perempuan memiliki kesulitan untuk berkomunikasi secara verbal.

Tato yang tidak hanya dipandang sebagai kajian lama mengenai kebudayaan primitif, namun hal tersebut tidak menjadikan alasan menghalalkan tato sebagai perilaku yang dianggap umum dan biasa. Terlebih orang tua di zaman dahulu dan sekarang pun terkhususnya di Kota Bengkulu sendiri masih melihat tato sebagai bentuk aib. Maka dari itu pentingnya penelitian ini dilakukan agar kita dapat mengetahui bagaimana makna tato sebagai media ekspresi pada masyarakat pengguna tato di kota Bengkulu.

\section{METODE PENELITIAN}

Jenis penelitian ini menggunkan metode kualitatif. Menurut Bogdan dan Taylor (1975:5) sebagaimana dikutip oleh Lexy J. Moleong dalam buku "Metodologi Penelitian Kualitatif" mengatakan bahwa kualitatif didefinisikan sebagai prosedur penelitian yang menghasilkan data deskriptif berupa kata-kata tertulis atau lisandari orang-orang dan perilaku yang dapat diamati (Moleong,2002:3). Dimana dalam penelitian ini peneliti akan mengumpulkan data dan informasi dari pengguna tato dengan cara melihat, mendengar dan mengamati lingkungan pengguna tato tersebut.

\section{InformanPenelitian}

Informan penelitian adalah orang yang memberikan informasi, dengan pengertian ini maka informan dapat dikatakan sama dengan responden apabila memberikan keterangannya karena dipancing oleh peneliti. (Arikunto, 2002:122). Dalam penelitian ini penulis mengambil ada sebanyak 5 orang informan, yang terdiri dari 3 orang laki-laki dan 2 orang perempuan.

\section{Teknik Pengambilan Informan}

Teknik pengambilan informan dilakukan menggunakan metode snowball sampling yaitu teknik bola salju yang turun menggelinding dari puncak gunung kelembah, semakin lama semakin besar ukurannya. Teknik ini merupakan teknik penentuan sampel yang awalnya berjumlah kecil, kemudian berkembang semakin banyak. Orang yang dijadikan sampel pertama diminta memilih atau menunjuk orang lain untuk dijadikan sampel lagi, begitu seterusnya sampai jumlahnya lebih banyak. (Rachmat Krisyantono,2014: 160).

\section{Teknik Pengumpulan Data}

1. Observasi

Secara harfiah observasi diturunkan dari bahasa latin yang berarti "melihat" dan "memperhatikan". Diungkapkan oleh Marshall (dalam Sugiyono, 2010) observasi merupakan metode pengumpulan data dimana peneliti belajar tentang perilaku dan makna dari perilaku tersebut. Dalam penelitian ini, peneliti menggunakan teknik observasi non partisipan, yakni observasi dimana peneliti tidak ikut memposisikan 
dirinya sebagai anggota atau kelompok yang diteliti.

2. Wawancara

Wawancara dilakukan dengan terpimpin dan terstruktur, dimana peneliti menggunakan pedoman wawancara (interview guide/schedule), yang merupakan bentuk spesifik yang berisi intruksi yang mengarahkan peneliti dalam melakukan wawancara. Pertanyaan yang akan diajukan kepada responden sudah disusun secara sistematis, biasanya mulai dari yang mudah menuju yang lebih kompleks. (Kriyantono, $2014: 101$ ).

3. Dokumentasi

Dokumen merupakan catatan peristiwa yang telah lalu, dokumen ini bisa berbentuk gambar, tulisan atau karyakarya monumental seseorang (Ahmedi, Narbuko 2009:83). Diajukan untuk memperoleh data langsung dari tempat penelitian. Diseleksi dan diolah guna mengetahui apakah data tersebut selanjutnya disiapkan atau dianalisis. Peneliti akan mendokumentasikan semua kegitan dalam proses pengumpulan data tersebut, seperti karya-karyai lmiah terdahulu, foto tato di tubuh informan dan lain-lain.

\section{TeknisAnalisis Data}

Analisis data merupakan bagian yang sangat penting dalam metode ilmiah. Karena dengan analisis data tersebut dapat diberi arti dan makna yang berguna dan memecahkan masalah penelitian. Analisa data adalah proses mengelola, memisahkan, mengelompokkan dan memandukan sejumlah data yang dikumpulkan baik di lapangan maupun dari dokumen. Kegiatan analisa data ini merupakan suatu proses penyederhanaan data kepada bentuk yang mudah di baca dan selanjutnya diinterpretasikan. Datadata yang telah terkumpul dan sudah diinterpretasikan itu. Selanjutnya akan dianalisis berdasarkan teori-teori yang ada.

Penulis mencari gambar tato yang memiliki makna dan arti dari tubuh informan, kemudian dianalisis menggunakan analisis semiotik model Charles Sanders Peirce. Setelah itu menarik kesimpulan untuk memperoleh arti dan makna dari tanda yang lebih mendalam dan luas terhadap hasil penelitian yang di lakukan. Setelah data primer dan skunder terkumpul, kemudian diklarifikasikan sesuai dengan pertanyaan penelitian yang telah ditentukan. Setelah data terklarifikasi, dilakukan analisis data dengan menggunakan teknik analisis semiotika Charles Sander Peirce. Peirce mengembangkan teori segitiga makna (triangel meaning) yang terdiri atas tanda (singn), objek (object), dan interpretan (interpretant). Menurut Pierce salah satu bentuk tanda adalah kata, sedangkan objek adalah sesuatu yang dirujuk tanda (Sobur, 2006 : 114-115). Sementara interpretan adalah tanda dalam benak seseorang tentang objek yang dirujuk sebuah tanda. Charles Sanders Pierce juga menyebut tanda sebagai suatu pegangan seseorang akibat ketertarikan dengan tanggapan atau kapasitasnya (Berger, $2000: 1$ )

Dalam penelitian ini, untuk menghasilkan hasil yang sesuai dengan tujuan, penulis menggunakan analisis semiotik model Charles Sanders Peirce. Semiotik merupakan ilmu yang mempelajari suatu tanda. Semiotika berangkat dari tiga elemen, yakni yang disebut Peirce sebagai teori segitiga makna atau triangle meaning.

1. Tanda (Sign)

Sesuatu yang berbentuk fisik yang dapat ditangkap oleh panca indera manusia. Tanda dalam penelitian ini ialah tato, pada tahap ini peneliti akan mencari individu yang memliki tato di area tubuh.

2. Acuan Tanda (Object)

Sesuatu yang dirujuk, atau dapat dikatakan sebagai tujuan. Lalu dalam proses ini peneliti akan menentukan tato yang mana yang dapat menjadi objek penelitian. 
3. Penggunaan Tanda (Interpretant)

Pemikiran seseorang tentang objek tersebut. Yakni peneliti akan mencari tahu seperti apa para individu yang memiliki tato mengisyaratkan tato tersebut.

Menurut Charles Sanders Peirce kata "semiotika", kata yang sudah digunakan sejak abad kedelapan belas oleh ahli filsafat Jerman Lambert, dahulu kata semiotika merupakan sinonim kata logika. Sedangkan penalaran, menurut hipotesis Charles Sanders Pierce yang mendasar dilakukan melalui tanda-tanda. Tandatanda memungkinkan menusia berfikir, berhubungan dengan orang lain dan member makna apa yang ditampilkan oleh alam semesta.

\section{HASIL PENELITIAN DAN PEMBAHASAN}

Berdasarkan hasil penelitian yang telah dilakukan oleh penulis, bahwasanya pengguna tato di kota Bengkulu memilih tato sebagai media mereka dalam mengekspresikan diri, seperti ekspresi diri kecewa yang dapat kita lihat pada tato anak panah yang dimiliki Anggie, ekspresi diri marah pada tato tenggorak bunga mawar yang dimiliki Ratna, ekspresi diri ungkapan terhadap kebebasan hidup yang terdapat pada tato punk dan tato tikus yang dimiliki Santa.

Selain itu juga, ada melalui ekspresi diri identitas pekerjaan seseorang yang dapat dilihat pada gambar tato gunting dan mesin jahit yang dimiliki Yudi. Hal tersebut senada dengan oleh Olong dimana menurut Olong, tato ialah media ekspresi diri yang membawa nilai-nilai identitas perlawanan, pencarian identitas, luapan cinta untuk kesenangan atau kenyamanan bagi penggunanya. Namun dalam penelitian ini peneliti menemukan hal-hal baru yang tidak ditemukan pada penelitian sebelumnya yaitu tato juga merupakan media ekspresi diri sebagai bentuk kekaguman akan sosok suatu figur yang dapat kita lihat pada tato queen Isabella 1 yang dimiliki Maya dan peneliti juga menemukan bahwa tato memiliki unsure candu.

Hal tersebut dibuktikan dari kesemua informan bahwa mereka memiliki tato yang jumlahnya rata-rata lebih dari satu, ada sebagian informan yang tubuhnya hampir dipenuhi dengan berbagai macam tato. Dan juga menurut salah satu pernyataan dari informan yang bernama Anggie bahwa tato tidak hanya sebatas seni saja namun tato juga telah masuk ke dunia industri perekonomian.

Dalam penelitian ini, peneliti juga menemukan berbagai macam makna dari pengguna tato tersebut. Didalam pembahasan ini, peneliti akan mengacu pada tiga kategori yakni tanda (qualisign, sinsign, legisign), objek (icon, index, symbol) dan interpretant (rheme, dicisign, argument). Yang dimaksud dengan tanda (sign) pada penelitian ini ialah tato yang ada ditubuh informan. Tato yang ada ditubuh informan merupakan tanda bagi mereka, tato juga merupakan hasil dari pemikiran pengguna tato sendiri sehingga tato atau tanda yang ada di tubuh informan merupakan sebuah gagasan tertentu.

\section{Qualisign}

Qualisign dalam penelitian ini ialah kualitas yang ada pada tato tersebut. Seperti yang kita tahu pada tato tengkorak berkepala bunga mawar yang dimiliki oleh Ratna Agke, dapat kita lihat bentuk tato yang lumayan besar dan menggabungkan dua unsure tengkorak dan bunga mawar. Tato ini terlihat unik karena biasanya gambar tato tengkorak secara garis besar di pakai oleh kaum laki-laki namun hal tersebut kita temukan pada kaum perempuan. Disisi lain kualitas tato Ratna tersebut dapat juga kita lihat dari penggunaan pingmen-pingmen warna yang mencolok, karena warna-warna yang terang akan membuat tato semakin mahal dan terlihat berkelas. 


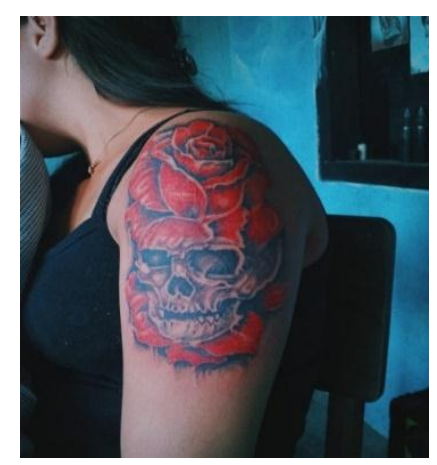

Gambar 1. Tato Tengkorak Bunga Mawar

\section{Sinsign}

Sinsign dalam penelitian ini adalah seberapa sering tato tersebut menjadi bagian dari diri penggunanya. Hal ini dapat kita lihat pada tato Yudi Nopriansyah yakni tato yang bergambarkan mesin jahit dan gunting. Tato ini merupakan tato yang menjadi identitas profesi pekerjaan yang ia lakukan sehari-hari karena dia berprofesi sebagai tukang jahit sebagaimana yang kita tahu bahwa tukang jahit sangat identik dengan kedua alat perkakas tersebut yakni mesin jahit dan gunting.
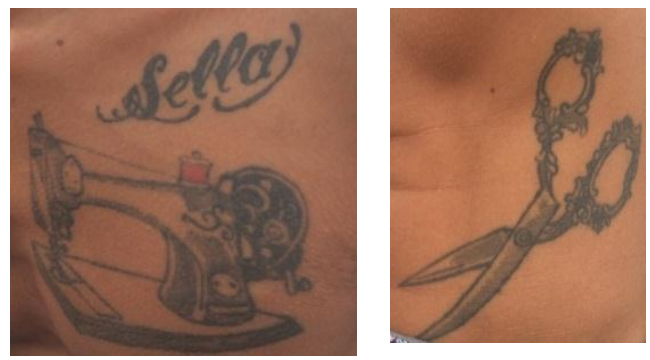

Gambar 2. Tato Gunting dan Mesin Jahit

\section{Legisign}

Legisign adalah norma yang dikandung oleh tato. Didalam penelitian ini ialah adakah aturan khusus dalam membuat gambar tato. Penulis menemukan bahwasannya tidak ada aturan baku dalam pembuatan gambar tato di tubuh informan, semua tato yang mereka buat telah melalui proses modifikasi sesuai selera mereka masing-masing dan tidak ada normanorma khusus yang harus mereka penuhi dalam gambar pembuatan tato tersebut.
Seperti halnya tato pada tangan Yudi Nopriansyah dimana ia membuat tato buah nanas kepala tengkorak.

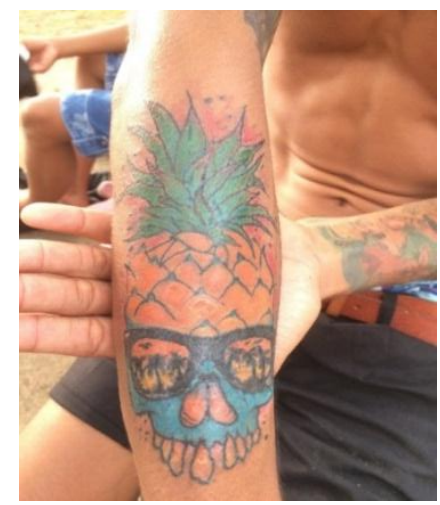

\section{Gambar 3. Tato Buah Nanas Kepala} Tengkorak

Tato berdasarkan objek yakni gambar tato yang menjadi pilihan dari informan. Berikut peneliti pecah dalam tiga aspek objek:

\section{Icon}

Icon atau ikon dalam penelitian ini ialah merupakan pemilihan tato yang ada ditubuh informan, dimana mereka memilih tato sebagai bentuk atau gambaran dari diri mereka masing-masing. Mereka merasa suatu tato tersebut merupakan cerminan dari diri mereka saat ini. Dalam penelitian ini seperti Maya Cherli yang memiliki tiga tato besar di tubuhnya. Tato tersebut ialah tato wajah para queen terdahulu seperti Queen Dwi Siren, Queen Isabella 1 dan tato pernak-pernik seorang queen yakni mahkota, kue cake dan bintang-bintang. Maya merasa jika paras dan kehidupannya layak seperti queen yang ada pada tatonya. Karena dia mendambakan atau mengidolakan menjadi seorang queen.

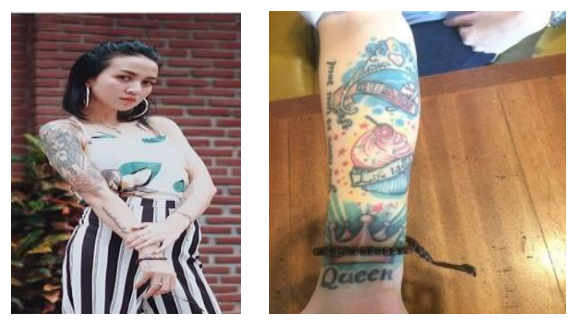

Gambar 4. Tato Pada Tubuh Maya Cherli 


\section{Index}

Index atau indeks dalam penelitian ini ialah terkait dengan ekspresi diri apa yang ingin informan ungkapkan sehingga memilih media tato. Dapat kita lihat pada Anggie yang mana ada dua ekspresi diri yang ia ungkapkan yakni berawal dari ekspresi diri kecewa hingga berakhirnya ungkapan cinta. Angie mengungkapkan ekspresi diri kecewa dengan tato anak panah dilehernya dan berakhir dengan ekspresi diri ungkapan cinta dengan tato dua anak laki-laki di kedua tangannya.

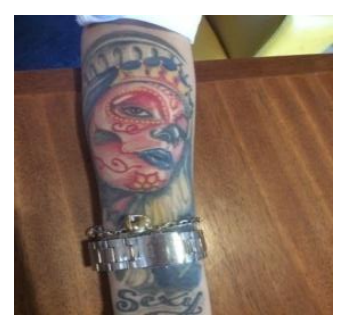

Gambar 5. Tato Pada Tubuh Anggie

\section{Symbol}

Symbol atau symbol dalam penelitian ini ialah makna atau arti dari tato yang ada dibadan informan. Pada dasarnya bunga mawar merupakan sebuah lambing kecantikan dan keindahan sosok wanita. Tato bunga mawar ini dapat kita lihat pada tato Yudi Nopriansyah dan Ratna Agke, namun mereka berdua mempunyai pemaknaan sendiri akan tato mawar yang ada di badan mereka masing-masing, yakni tato mawar hitam pada tangan kiri Yudi bermakna ia pernah mencintai seseorang wanita malam sedangkan mawar hitam merupakan fiksi karena mawar hitam tidak akan kita temui di alam. Mawar identik dengan wanita dan hitam merupakan suatu yang berkabung. Sedangkan Ratna Agke memaknakan mawar tersebut melambangkan kepribadiannya yang cantik, harum, indah, menarik dan tidak murahan.

Lalu tato sosok figure yaitu queen, tato tersebut dapat kita temui pada tato yang dimiliki oleh Maya Cherly dan Ratna Agke seperti tato queen Dwi Siren, queen Isabella 1, Tinkerbell dan tato Doraemon.
Dimana antara Maya dan Ratna memiliki persamaan dalam mengartikan tato figure tersebut, yakni mereka merasa bahwa ada kesamaan sifat dan fisik terhadap tato figure tersebut. Mereka mengaku bahwa kecantikan kesempurnaan dan kesaktian dari figure tersebut terdapat di diri mereka seperti cantik, seksi, kuat, mandiri, menggoda, dan lain-lain.
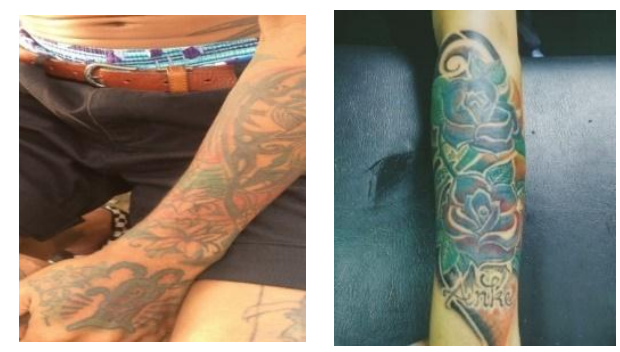

Gambar 6. Tato MawarYudi dan Ratna
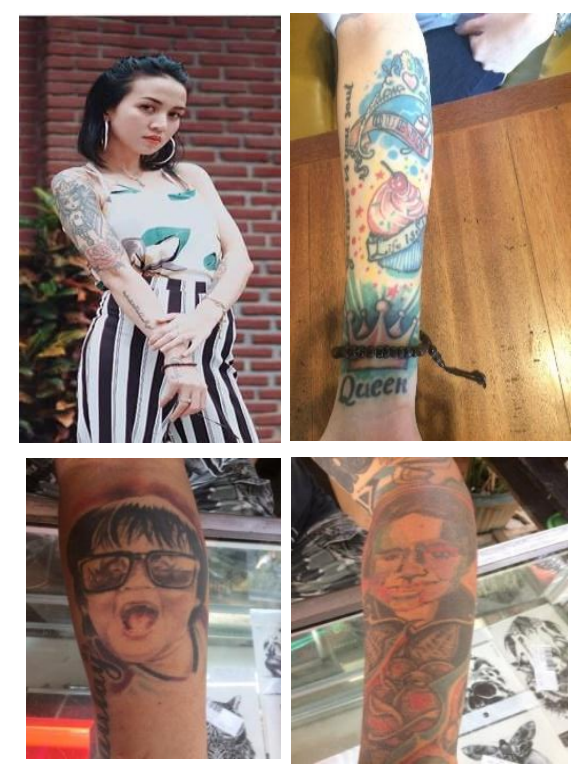

Gambar 7. Tato Figur Ditubuh Maya dan Ratna

Tato berdasarkan interpretan, berikut peneliti pecah dalam tiga aspek interpretan: (rheme, dicisign, argument).

\section{Rheme}

Rheme merupakan tanda yang memungkinkan ditafsirkan dalam pemaknaan yang berbeda-beda hal ini senada dengan gambar tato mawar yang digunakan oleh yudi dan Ratna dimana mereka berdua mempunyai arti yang 
berbeda terhadap tato bunga mawar tersebut.

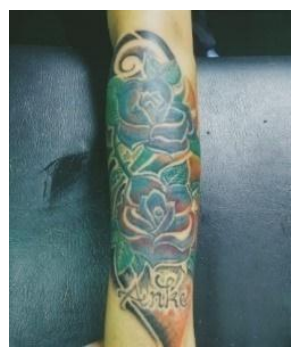

Gambar 8. Tato Bunga Mawar DitubuhYudi dan Ratna

\section{Dicisign}

Dicisign merupakan tanda yang sesuai dengan fakta dan kenyatan. Hal ini senada dengan bukti dilapangan yang penulis temukan pada tato gunting dan mesin jahit yang dimiliki oleh Yudi, dimana tato tersebut merupakan bukti pekerjaannya sebagai tukang jahit.
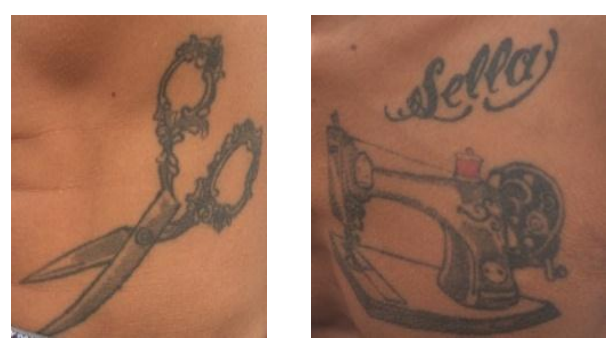

Gambar 9. Tato Gunting dan Mesin Ditubuh Yudi

\section{Argument}

Argument merupakan tato yang berisi alasan tentang suatu hal. Peneliti penemukan bahwasannya semua tato yang dimiliki informan merupakan alasanalasan mengapa mereka membuat tato-tato tersebut. Dapat kita simpulkan bahwa semua tato yang ada ditubuh informan tersebut merupakan hasil dari apa yang mereka fikirkan dan tato yang mereka miliki bukan hanya sebatas sebuah gambar saja melainkan terdapat filosofi didalamnya.

\section{PENUTUP}

\section{Kesimpulan}

Berdasarkan hasil penelitian dan pembahasan dapat disimpulkan bahwa tato merupakan seni menyampaikan ekspresi diri yang melambangkan symbol atau tanda yang memiliki makna. Ekspresi diri pada masyarakat pengguna tato terhadap tato yang mereka gunakan ditemukan bahwa mereka ingin menyampaikan ekspresi diri kecewa, identitas diri, dan rasa cinta. Selanjutnya, makna tato sebagai media ekspresi diri pada masyarakat pengguna tato di kota Bengkulu adalah bervariasi, seperti: nyawa serasa sudah sampai di tenggorokan, cinta kepada anak dan bangga menjadi seorang ayah, perbandingan antara punk dan koruptor, cinta kepada ibu, kado ulang tahun untuk istri, cinta terhadap profesi, kekecewaan karena terlahir dari kelurga broken home, benci kepada ayah, harapan hidup ingin menjadi seorang queen.

Hal ini dapat dilihat dari penjelasan berikut ini yakni, tanda atau sign dikaitkan dengan ground di bagi menjadi qualisign (sangatlah mendalam hal tersebut terkait dengan perjalanan hidup yang ia lalui selama ini), sinsign (memperlihatkan dalamnya ekspresi kecewa dan bahagia yang dirasakan), dan legisign (tidak ada bentuk aturan baku ia menggunakan tato, tato yang ada dibadannya merupakan tato yang sudah hasil modif sesuai seleranya).

Berdasarkan objeknya, tanda dibagian atas ikon (icon), indeks(index), simbol (symbol) yakni, Indeks (ekspresi dirikecewa yang berujung ungkapan cinta), Icon (mereka memilih tato sebagai bentuk atau gambaran dari diri mereka masingmasing, dapat kita lihat pada tato sosok queen yang dimiliki oleh Maya), Simbol (bunga mawar merupakan sebuah lambing kecantikan dan keindahan sosok wanita. Tato bunga mawar ini dapat kita lihat pada tatoYudi Nopriansyah dan Ratna Agke, namun mereka berdua mempunyai pemaknaan sendiria kan tato mawar).

Berdasarkan interpretant, tanda dibagi atas rheme, dicisign), symbol argument, yakni, Rheme (tanda yang memungkinkan ditafsirkan dalam pemaknaan yang berbeda-beda hal ini senada dengan gambar tato mawar yang digunakan oleh Yudi dan ratna dimana mereka berdua 
mempunyai arti yang berbeda terhadap tato bunga mawar tersebut, Dicisign (merupakan tanda yang sesuai dengan fakta dan kenyatan. Hal ini senada dengan bukti dilapangan yang penulis temukan pada tato gunting dan mesin jahit yang dimiliki oleh Yudi, dimana tato tersebut merupakan bukti pekerjaannya sebagai tukang jahit), Argument (merupakan tato yang berisi alasan tentang suatu hal. Peneliti penemukan bahwasannya semua tato yang dimiliki informan merupakan alasan-alasan mengapa mereka membuat tato-tato tersebut).

\section{Saran}

1. Diharapkan kepada pengguna tato untuk lebih membuka diri, perbanyak melakukan aksi-aksi sosial, dan untuk mempertimbangkan kembali keputusan untuk menambah tato, mengingat banyak sekali resiko gangguan kesehatan yang akan terjadi, seperti rentan terkena virus HIV yang dapat ditularkan dari jarum pada saat proses pembuatan tato.

2. Kepada individu atau masyarakat yang baru ingin menggunakan tato untuk dapat mempertimbangkan kembali menggunakan tato dan disarankan untuk dapat memilih media ekspresi diri selain tato.

3. Disarankan kepada peneliti berikutnya untuk melihat bagaimana pandangan masyarakat umum dalam melihat minoritas pengguna tato di Kota Bengkulu, dengan menggunakan metode dan teori yang lain agar kajian lebih mendalam lagi, sehingga hasil penelitian ini dapat dijadikan sebagai bahan referensi rujukan bagi peneliti selanjutnya.

\section{DAFTAR PUSTAKA}

Ahmadi, Abu dan Chaolid Narbuko. 2009. Metodologi Penelitian. Jakarta, PT. Bumi Aksara.

Ardianto, dkk. 2007. Filsafat Ilmu Komunikasi. Bandung, Simbiosa Rekatama Media
Arikunto, S. 2002. Metodologi Penelitian Suatu Pendekatan Proposal. Jakarta, PT. Rineka Cipta

Daryanto. 1998. Kamus Lengkap Bahasa Indonesia. Surabaya, Apollo Lestari.

Ghufron, M Nur dan Rini Risnawita S. 2012. Teori-Teori Psikologi. Jogyakarta, Ar-Ruzz Media.

Fiske, John. 2012. Pengantar Ilmu Komunikasi. Jakarta, PT. Raja Grafindo Persada

Hasan, M. Iqbal. 2002. Pokok-Pokok Materi Metodologi Penelitian dan Aplikasinya. Bogor, Ghalia Indonesia.

Kriyantono, Rachmat. 2014. Teknik Praktis Riset Komunikasi. Jakarta, Kencana Prenadamedia Group

Marianto, M Dwi Dan Samsul Barry. 2000. Tato. Yogyakarta, Lembaga Penelitian Institut Seni Indonesia.

Moleong, Lexy. 1990. Metodelogi Penelitian Kualitatif. Bandung, Remaja Rosdakarya.

Moleong, Lexy. 2002. Metodologi Penelitian Kualitatif. Bandung, PT. Remaja Rosdakarya.

Olong Kadir, Hatib Abdul. 2006. Tato. Jakarta, PT LKIS PelangiAksara

Rakhmat, Jalaludin. 1997. Metode Penelitian. Bandung, PT. Remaja Rosdakarya.

Rogers, Everett. 1994. A History of Communication Study. New York, The Free Press

Sarwono, Jonatan. 2006. Metode Penelitian Kuantitatif \& Kualitatif. Yogyakarta, Graha Ilmu.

Sugiyono, 2008. Metode Penelitian Kuantitatif, Kualitatif dan $R \& D$. Bandung, Alfabeta.

Sugiyono. 2010. Metode Penelitian Pendidikan Pendekatan Kuantitatif, Kualitatif dan R\&D. Bandung, Alfabeta.

Sobur, Alex. 2003. Psikologi Umum. Bandung, Pustaka Setia.

Sobur, Alex. 2006. Semiotika Komunikasi. Bandung, PT. Remaja Rosdakarya 
Jurnal Professional FIS UNIVED Vol.6 No. 2 Desember 2019

Vera, Nawiroh. 2015. Semiotika Dalam Riset Komunikasi. Bogor, Ghalia Indonesia.
Wibowo, Wahyu. 2011. Semiotika

Komunikasi. Jakarta, Mitra Wacana Media. 